ISSN: 2085-0344 (Print)

ISSN: 2503-1864 (Online)

Journal homepage: www.ejournal.almaata.ac.id/literasi

Journal Email: literasi_stia@yahoo.com

\title{
Penguatan Karakter Nasionalisme Generasi Alpha Melalui Living Values Education Program (LVEP)
}

\author{
An-Nisa Apriani', Indah Perdana Sari \\ PGSD Universitas Alma Ata Yogyakarta \\ Email: annisa.apriani@almaata.ac.id
}

\begin{abstract}
Abstrak
Penelitian ini bertujuan untuk memaparkan tentang cara menguatkan karakter nasionalisme generasi alpha di era digital melalui Living Values Education Program (LVEP). Metode penelitian yang digunakan yaitu penelitian studi kepustakaan. Data yang dibutuhkan dalam penelitian yaitu data sekunder yang berupa buku-buku ilmiah, jurnal ilmiah, laporan penelitian, dan sumber lain yang relevan. Teknik analisis data dalam penelitian meliputi organize, synthesize, dan identify. Hasil penelitian ini menunjukkan bahwa nilai-nilai LVEP yang mencakup nilai kerjasama, kebebasan, kebahagiaan, kejujuran, kerendahan hati, cinta, kedamaian, penghargaan, tanggung jawab, kesederhanaan, toleransi,dan persatuan memiliki relevansi yang kuat dalam penanaman karakter nasionalisme generasi alpha di era digital. Aktivitas nilai-nilai LVEP yang meliputi kegiatan berimajinasi, berdialog, berkomunikasi, refleksi, berkreasi, menyatakan diri lewat seni, membuat tulisan, dan bermain dengan nilai-nilai yang diajarkan dapat dijadikan sebagai program inovatif dan kreatif dalam proses pembelajaran yang bertujuan untuk penguatan karakter nasionalisme anak-anak generasi alpha di era digital darisajian informasi dan budaya yang tidak sesuai dengan nilai-nilai pancasila.
\end{abstract}

\section{Kata kunci:nasionalisme, generasi alpha, living values education program}

\begin{abstract}
Abstrak
This study attempts to discuss how to strengthen character nationalism generation alpha in the digital era through living values education program (LVEP). Methods used in the research is literature available study (library research).Data in the research is secondary data in the form of scientific books, scientific journals, and other relevant sources. Data analysis technique in this research consist of three steps, organize, synthesize, and identify. The result of this research indicates that LVEP values which includes the value of cooperation, freedom, happiness, honesty, humility, love, peace, respect, responsibility, simplicity, tolerance, and the association of having relevant in the planting of strong character nationalism generation alpha in the digital era .

The values activities of LVEP which includes activities of reflection, imaging, engaging in dialogue, communicating, creating, making of script, proclaiming in self through art, and playing with values that taught can be used as the innovative programs and creative in learning process which is intended to strengthen the nationalism character on child especially Alpha generation in the era of digital that provides information and culture which is not in accordance with the values of pancasila (5 foundationals philosophical.theory of Indonesian state).
\end{abstract}

Keywords: nationalism, alpha generation, living values education program 


\section{PENDAHULUAN}

Globalisasi adalah keterkaitan dan ketergantungan antar bangsa dan antarmanusia di seluruh dunia melalui perdagangan, investasi, perjalanan, budaya, dan bentuk-bentuk interaksi yang lain sehingga batas-batas suatunegara menjadi semakin sempit. ${ }^{1}$ Banyak kalangan menyadari bahwa globalisasi membawa beberapa dampak positif, diantaranya lebih canggihnya komunikasi, transportasi yang lebih cepat dan lain-lain. Namun, globalisasi juga membawa beberapa dampak negatif. Globalisasi mengakibatkan banyaknya budaya yang masuk dan menyebabkan berbagai masalah di negeri ini, misalnya menurunnya rasa cinta budaya dan nasionalisme generasi muda. Senada dengan pendapat tersebut, Hendrastomo, G. menambahkan bahwa paham nasionalisme semakin terkikis oleh paham globalisme di era modern. ${ }^{2}$

Nasionalisme adalah perasaan satu sebagai suatu bangsa, satu dengan seluruh warga yang ada dalam masyarakat. Ketua Majelis Permusyawaratan Rakyat (MPR RI), Zulkifli Hasan mengungkapkan bahwa nasionalisme menjadi alat perjuangan, semacam pilar untuk membangun pondasi dan merajut kebhinekaan seiring dengan rezim yang dilewati bangsa Indonesia. ${ }^{3}$ Sikap nasionalisme mencakup cinta tanah air, rela berkorban demi bangsa, menghargai jasa para pahlawan, mengutamakan kepentingan orang banyak, membina persatuan dan kesatuan, bangga pada budayayang beragam, bangga sebagai bangsa Indonesia, toleransi terhadap perbedaan, cinta terhadap lingkungan, dan berkerja sama. ${ }^{4}$

${ }^{1}$ M. Irsyad Musa."Dampak Pengaruh Globalisasi Bagi Kehidupan Bangsa Indonesia”. Jurnal Pesona Dasar, 3(3).no.3 (2015): 2.

${ }^{2}$ Grendi Hendrastomo. "Nasionalisme vs Globalisasi 'Hilangnya'Semangat Kebangsaan dalam Peradaban Modern.” DIMENSIA, no.1 (2005): 1.

${ }^{3}$ Anne Rufaidah. "Menyongsong Tantangan Nasionalisme di Era Digital." Diunduh pada tanggal 20 Agustus 2019. Dari https://kemahasiswaan.itb.ac.id/ welcome/tampil_berita/107/menyongsong-tantangannasionalisme-di-era-digital.

${ }^{4}$ An-Nisa Apriani dan Yusinta Dwi Ariyani.
Nasionalisme bangsa Indonesia melahirkan ideologi negara, yaitu Pancasila. Ideologi Pancasila terdapat lima prinsip nilai yang bersifat dasar dan menjadi ajaran pokok yang digunakan sebagai pedoman bagi seluruh warga bangsa Indonesia, baik dalam tataran individu maupun kelompok.

Menghadapi dunia digital dengan budaya dan karakteristik generasi millennial saat ini, nasionalisme terhadap bangsa Indonesia menemui tantangan yang paling berat.Memasuki kemajuan teknologi yang begitu kuat, akhirnya nasionalisme harus menghadapi tantangan zaman. Menurut Zulkifli, tantangan pertama yakni kemajuan teknologi, komunikasi, dan informasi. Akibatnya, kebudayaan mulai bergeser dan nasionalisme generasi bangsa semakin menurun di era digital.Tantangan selanjutnya adalah globalisasi yang sangat berpengaruh pada kehidupan sosial budaya suatu bangsa. Bebasnya budaya asing yang masuk ke Indonesia, akibatnya mengubah pergeseran jiwa kebangsaan masyarakat Indonesia. ${ }^{5}$ Dengan demikian, generasi muda saat ini harus bisa memahami dan mengerti tentang arti nasionalisme di era digital agar bisa membawa dampak positif bagi bangsa.

Generasi bangsa saat ini rentan akan hilangnya perasaan dan perilaku Nasionalisme sebagaimana yang dilakukan oleh generasi bangsa sebelumnya. Sikap hormat dan bangga serta keinginan untuk meneladani pahlawan pendahulu bangsa bukan lagi menjadi motivasi generasi muda saat ini dalam menghadapi perkembangan zaman. ${ }^{6}$ Bahkan, kondisi

\footnotetext{
"Analisis Muatan Nilai-Nilai Nasionalisme Pada Buku Teks KTSP PKn Kelas 3 SDELEMENTARY SCHOOL (Jurnal Pendidikan dan Pembelajaran Ke-SD-an), 4(2). 2017: 65.

${ }^{5}$ Anne Rufaidah. "Menyongsong Tantangan Nasionalisme di Era Digital." Diunduh pada tanggal 20 Agustus 2019. Dari https://kemahasiswaan.itb.ac.id/ welcome/tampil_berita/107/menyongsong-tantangannasionalisme-di-era-digital.

${ }^{6}$ Anonim. "Nasionalisme di Era Digital.'Diunduh pada tanggal 28 Agustus 2019. Dari http://www. tribunnews.com/nasional/2016/03/29/nasionalisme-eradigital.
} 
nasionalisme generasi muda Indonesia di era digital mencerminkan degradasi moral. Hal tersebut di tunjukkan dengan beritaberita di media massa yang menunjukkan perilaku generasi muda saat ini semakin tidak menunjukkan lima prinsip nilai dasar pancasila. Pudarnya nasionalisme di Indonesia saat ini dapat dilihat dari adanya kasus kekerasan yang ditemukan sepanjang tahun 2016 seperti intoleransi, radikalisme, terorisme, dan separatisme, adanya fakta bahwa ada 5,1 juta pengguna narkoba dan 15.000 orang meninggal setiap tahun, meningkatnya pornografi dan cyber crime sepanjang tahun 2011-2015, serta krisis kepribadian bangsa dan melemahnya kehidupan berbangsa dan bernegara. ${ }^{7}$ Kasuskasus tersebut semakin mencemaskan dan mengakibatkan perilaku dan kebiasaan anakanak sekarang berlawanan dari norma, nilai, dan budaya Bangsa.

Kondisi nasionalisme generasi muda yang rendah dan buruk dapat berakibat pada kehancuran bangsa di masa depan. Lingkungan pendidikan memegang kunci utama penanaman karakter nasionalisme peserta didik. Lingkungan keluarga, sekolah, dan masyarakat harus bekerja sama untuk membangun karakter nasionalisme generasi masa kini dan masa depan yang disebut generasi alpha. Generasi alpha adalah anakanak yang lahir setelah tahun 2010. Generasi alpha lahir dari bapak ibu generasi milenial. Generasi alpha merupakan generasi yang paling sering bersosialisasi dengan internet. Generasi yang paling dekat dengan teknologi digital dan generasi paling cerdas dibanding generasigenerasi sebelumnya. Namun, fasilitas dan teknologi yang lengkap dan canggih membuat mereka menjadi generasi yang memiliki daya juang paling rendah, memiliki kekurangan, seperti bossy, dominan, suka mengatur; tak suka berbagi; tidak mau mengikuti aturan; teknologi menjadi bagian dari hidup mereka, dan tidak akan mengetahui dunia tanpa jejaring sosial;

${ }^{7}$ Arie Budhiman. "Gerakan Penguatan Pendidikan Karakter.”Diunduh pada tanggal 24 Agustus 2019. Dari cerdasberkarakter.kemdikbud.go.id/ content/ download/44. dan kemampuan berkomunikasi langsung rendah. ${ }^{8}$

Karakter nasionalisme perlu dibentuk sejak usia dini dengan tujuan pembangunan generasi alpha sebagai sumber daya manusia Indonesia yang memiliki akhlak mulia, berkompeten, dan berkualitas. Penanaman sikap nasionalisme wajib ditanamkan sejak usia dini agar karakter tersebut lebih melekat pada saat mereka beranjak dewasa. Orang tua dan guru harus membangun jiwa kebangsaan yang kuat dan semangat kepahlawanan kepada anak-anak Indonesia agar kelak mereka saat memimpin bangsa tidak mudah dipecah belah oleh kemajuan teknologi. ${ }^{9}$ Dengan demikian dunia pendidikan dipandang memiliki peran yang strategis dalam penguatan karakter nasionalisme.

Penanaman dan penguatan karakter nasionalisme dapat dilakukan melalui pendidikan di sekolah karena sekolah adalah dasar yang kuat dan penting dalam menumbuhkan norma, kebiasaan dan keyakinan, sehingga terbentuk karakter yang kuat untuk menghadapi kehidupan yang dinamis dan beragam. Peran guru sangat penting dalam membangun karakter nasionalisme dengan cara penanaman nilai kasih sayang, nilai keteladanan, perilaku positif, moralitas, dan nilai-nilai kebhinnekaan. ${ }^{10}$ Guru merupakan sumber daya manusia yang di harapkan untuk menanamkan dan menguatkan kara kter nasionalisme pada generasi alphadalam pembelajaran.

Arifudin, I. S menjelaskan bahwa guru memiliki peran dalam menanamkan nilai karakter pada diri siswa dengan kondisi

${ }^{8}$ Sigit Purnomo. "Pengasuhan Digital Untuk Anak Generasi Alpha." Al Hikmah Procedings Islamic Early Childhood Education, 1(4). (2018): 493.

${ }^{9}$ An-Nisa Apriani dan Yusinta Dwi Ariyani. "Analisis Muatan Nilai-Nilai Nasionalisme Pada Buku Teks KTSP PKn Kelas 3 SD.”Elementary School (Jurnal Pendidikan dan Pembelajaran Ke-SD-an), 4(2). (2017): 174.

${ }^{10}$ Kemendikbud Republik Indonesia. "Kajian dan Pedoman Penguatan PendidikanKarakter (PPK)." (Jakarta: Kementerian Pendidikan dan Kebudayaan Republik Indonesia, 2017). 
suasana kelas yang kondusif, nyaman dan menyenangkan.Guru memiliki peran penting dalam mengembangkan pendidikan karakter karena guru adalah agen peradaban dan memiliki peran utama dalam pembelajaran. ${ }^{11}$ Guru diharapkan lebih kreatif, inovatif, dan adaptif dalam penggunaan strategi pembelajaran penanaman karakter yang menekankan pada moral knowing, moral feeling dan moral action dalam pembelajaran. Salah satu strategi pembelajaran yang dapat diterapkan yaitu Living Values Education Program(LVEP).

LVEP adalah program pendidikan yang membantu anak-anak dan remaja untuk menggali serta mengembangkan dua belas nilainilai universal seperti kerjasama, kebebasan, kebahagiaan, kejujuran, kerendahan hati, cinta, kedamaian, penghargaan, tanggung jawab, ksederhanaan, toleransi, dan persatuan sehingga nilai-nilai tersebut akan menjadi pembiasaan dalam kehidupan pribadi dan masyarakat luas serta menjadikan nilai-nilai tersebut bagian hidup mereka. ${ }^{12}$ Selanjutnya, keunggulan dari LVEP ini sudah diteliti oleh Apriani, A., Sari, I. P., \& Suwandi, I. K. yang menunjukkan bahwa penerapan model LVEP dalam pembelajaran tematik mampu meningkatkan karakter nasionalisme siswa SD. ${ }^{13}$ Penulis meyakini bahwa LVEP menjadi program unggulan penguatan pendidikan karakter khususnya nilai nasionalisme bagi anakanak generasi alpha dalam pendidikan formal sekolah. Penelitian ini bertujuan memaparkan tentang cara menguatkan karakter nasionalisme generasi alpha di era digital melalui Living Values Education Program (LVEP).

\footnotetext{
${ }^{11}$ Iman Syahid Arifudin. "Peranan Guru Terhadap Pendidikan Karakter Siswa Di Kelas V Sdn 1 Siluman." Pedadidaktika: Jurnal Ilmiah Pendidikan Guru Sekolah Dasar, 2(2), 175-186. (2015): 184.

${ }^{12}$ Diane Tillman, Living Values Activities For Children Ages 8-14(Jakarta: Gamedia, 2004).

${ }^{13}$ An-Nisa Apriani, Indah Perdana Sari, dan Intan Kurniasari Suwandi. "Pengaruh Living Values Education Program (LVEP) Terhadap Penanaman Karakter Nasionalisme Siswa SD Dalam Pembelajaran Tematik." Taman Cendekia: Jurnal Pendidikan Ke-SD-an, no 2 (2017): 102.
}

\section{METODE PENELITIAN}

Jenis penelitian yang digunakan adalah penelitan kepustakaan dengan pendekatan deskriptif kualitatif. Penelitian kepustakaan yaitu serangkaian penelitian yang berkenaan dengan data-data atau bahan-bahan yang berasal dari perpustakaan baik berupa buku, ensklopedi, kamus, jurnal, dokumen, majalah dan lain sebagainya. ${ }^{14}$ Khatibah menambahkan bahwa penelitian kepustakaan tidak hanya mengumpulkan, membaca dan mencatat literatur. Penelitian kepustakaan perlu memperhatikan beberapa langkah seperti metode penelitian dalam rangka mengumpulkan data, membaca dan mengolah bahan pustaka serta data yang harus dipersiapkan dalam penelitian tersebut yang bertujuan mempermudah peneliti dalam memperoleh data. ${ }^{15}$

Sumber data penelitian adalah sumber data sekunder. Sumber data sekunder yaitu bahan pustaka yang ditulis dan dipublikasikan seorang penulis. Analisis data dalam kajian pustaka ini adalah analisis isi yaitu pembahasan mendalam terhadap isi informasi baik tertulis maupun tercetak. Data dalam penelitian kepustakaan berupa hasil-hasil penelitian seperti buku-buku ilmiah, jurnal ilmiah, laporan penelitian, dan sumber lain yang relevan. ${ }^{16}$

Teknik analisis data dalam penelitian meliputi tiga tahap yaitu organize, synthesize, dan identify. Pertama, tahap organize yaitu mengorganisasikan literatur-literatur yang digunakan. Literatur yang akan digunakan direview terlebih dahulu agar relevan dengan permasalahan. Penulis mencari ide, tujuan, dan simpulan dari beberapa literatur dimulai dari membaca abstrak, pendahuluan, metode, dan pembahasan. Kedua, tahap synthesize yaitu menyatukan hasil organisasi literatur menjadi suatu ringkasan agar menjadi satu kesatuan

\footnotetext{
${ }^{14}$ Nursapia Harahap. "Penelitian Kepustakaan." Jurnal Iqra', 5(01), 68-73. (2014): 68.

${ }^{15}$ Khatibah Khatibah. "Penelitian kepustakaan." Iqra': Jurnal Perpustakaan dan Informasi, 5(01), (2011): 39.

${ }^{16}$ Sukmadinata, Metode penelitian(Bandung: PT Remaja Rosda Karya, 2011).
} 
yang padu dan utuh dengan cara mencari hubungan antar literatur. Ketiga, identify yaitu mengidentifikasi isu-isu kontroversi dalam literatur. Isu kontroversi adalah isu yang dianggap sangat penting untuk dianalisis dengan tujuan mendapatkan suatu tulisan yang menarik untuk dibaca.

\section{HASIL PENELITIAN DAN PEMBAHASAN Penguatan Pendidikan Karakter Definisi Penguatan Pendidikan Karakter}

Sekolah merupakan lembaga formal pendidikan yang memiliki tugas untuk menanamkan nilai karakter bagi generasi penerus bangsa. Sekolah dapat melaksanakan penguatan pendidikan karakter sesuai intruksi dari pemerintah melalui Gerakan Revolusi Mental. Upaya-upaya penguatan terhadap pendidikan karakter, juga sudah lama dilakukan pemerintah, diantaranya dengan melakukan Gerakan Nasional Pendidikan Karakter Bangsa Tahun 2010 yang kemudian dilajutkan dengan program Penguatan Pendidikan Karakter (PPK) pada tahun2016. Hal ini sesuai dengan salah satu butir Nawacita melalui Gerakan Revolusi Mental yang dimaklumatkan presiden Joko Widodo. ${ }^{17}$

Gerakan PPK menjadikan pendidikan karakter sebagai inti pendidikan nasional sehingga pendidikan karakter menjadi fokus dalam pelaksanaan pendidikan dasar dan menengah. Pendidikan karakter pada tingkat pendidikan dasar mendapatkan porsi yang lebih besar dibandingkan pendidikan yang mengajarkan pengetahuan (transfer of knowledge). ${ }^{18}$ Penguatan pendidikan karakter menempatkan karakter sebagai dimensi terdalam atau sebagai inti pendidikan nasional.Pendidikan karakter merupakan aspek penting dalam

${ }^{17}$ Yetri Hasan dan Rijjal Firdaos. "Penguatan Pendidikan Karakter Berbasis Masyarakat Pada Sekolah Menengah Pertama Negeri (SMPN) Di Kabupaten Tulang Bawang Provinsi Lampung." Al-Tadzkiyyah: Jurnal Pendidikan Islam, 8(2), (2018): 268.

${ }^{18}$ Kemendikbud Republik Indonesia. "Kajian dan Pedoman Penguatan PendidikanKarakter (PPK).” (Jakarta: Kementerian Pendidikan dan Kebudayaan Republik Indonesia, 2017). mengembangkan ranah afektif. Pendidikan nkarakter penting untuk ditanamkan pada anak usia sekolah dasar karena bertujuan membentuk pribadi siswa yang memiliki nilai-nilai luhur bangsa dan menjadi warga negara yang baik.

Kunci keberhasilan pelaksanaan penguatan pendidikan karakter dalam kurikulum 2013 terletak pada Tri Pusat Pendidikan yaitu lingkungan keluarga, sekolah, dan masyarakat. Lingkungan keluarga merupakan basis pertama pendidikan karakter bagi anak. Lingkungan sekolah memiliki peran yang strategis dalam pembentukan manusia yang berkarakter. Di sekolah, guru adalah tokoh utama yang diharapkan mampu mendidik peserta didik menjadi manusia yang berbudaya dan bermoral. ${ }^{19}$ Guru memiliki peran penting dalam mengembangkan pendidikan karakter karena guru adalah agen peradaban dan memiliki peran utama dalam pembelajaran. Guru harus berkomitmen untuk mengembangkan karakter siswa. Selanjutnya, hal yang paling penting dalam penanaman karakter yaitu guru harus berkarakter baik karena guru adalah teladan utama bagi siswa. ${ }^{20}$ Lingkungan masyarakat juga memiliki peran penting dan sangat mempengaruhi watak dan karakter manusia. Pendidikan dalam masyarakat memberikan dampak yang lebih luas. ${ }^{21}$ Lingkungan masyarakat berkontribusi dalam menanamkan dan memperkuat nilai-nilai karakter yang baik serta mencegah nilai-nilai buruk.

Berdasarkan ulasan di atas, penguatan pendidikan karakter adalah ruh utama dalam pendidikan nasional yang bertujuan memcetak generasi muda yang cerdas dan berkarakter. Keberhasilan penguatan pendidikan karakter

${ }^{19}$ Zubaedi, Desain Pendidikan Karakter: Konsespsi dan Aplikasinya dalam Lembaga Pendidikan(Jakarta: Prenada Media Grup, 2015).

${ }^{20}$ Putri Rachmadyanti. "Penguatan Pendidikan Karakter Bagi Siswa Sekolah Dasar melalui Kearifan Lokal."Jurnal Pendidikan Sekolah Dasar, 3(2), (2017): 208-209.

${ }^{21}$ Nasirudin. "Peran Keluarga, Sekolah, dan Masyarakat Dalam Pendidikan Karakter Generasi Muda Bangsa." Prosiding Seminar Nasional Tahunan Fakultas Ilmu Sosial Universitas Negeri Medan, no 1 (2017): 324. 
ditentukan oleh tiga lingkungan yaitu keluarga, sekolah, dan masyarakat. Ketiga lingkungan pendidikan memiliki peran yang penting dan pokok dalam penanaman dan pengembangan karakter anak sehingga harus terlibat kerja sama yang mendukung agar tujuan penguatan pendidikan karakter tercapai.

\section{Lima Nilai Karakter Prioritas PPK}

Terdapat lima nilai karakter utama yang bersumber dari Pancasila, nilai nilai karakter yang menjadi prioritas dalam gerakan PPK; yaitu religius, nasionalisme, integritas, mandiri dan gotongroyong. (1) Religius menunjukkan keberimanan terhadap Tuhan Yang Maha Esa, (2) Nasionalisme menempatkan kepentingan bangsa dan negara di atas kepentingan diri dan kelompoknya, (3) Integritas menempatkan dirinya sebagai orang yang selalu dapat dipercaya dalam perkataan, tindakan, dan pekerjaan, (4) Mandiri mencerminkan pada perilaku tidak bergantung pada orang lain dan menggunakan tenaga, pikiran, waktu untuk mencapai sebuah harapan, mimpi, dan citacita, dan (5) Gotong royong menunjukkan pada perilaku semangat kerja sama dalam menyelesaikan masalah bersama. Semua nila karakter saling berinteraksi satu sama lain agar nilai karakter berkembang secara dinamis dan membentuk keutuhan pribadi. ${ }^{22}$

Kelima nilai karakter utama tersebut saling melengkapi dan mendukung secara dinamis dalam membentuk pribadi yang berakhlak mulia baik vertikal maupun horisontal. Salah satu karakter utama yang perlu ditingkatkan di era globalisasi yang semakin mencekam dan mengakibatkan berbagai kriminal sehingga terjadi krisis moral generasi muda terhadap bangsanya adalah karakter nasionalisme.

\section{Karakter Nasionalisme}

Pendidikan karakter penting ditanamkan sejak usia dini. Dengan diberikan pendidikan

\footnotetext{
${ }^{22}$ Kemendikbud Republik Indonesia. "Kajian dan Pedoman Penguatan PendidikanKarakter (PPK).” (Jakarta: Kementerian Pendidikan dan Kebudayaan Republik Indonesia, 2017).
}

karakter sejak usia dini diharapkan anakanak mampu membedakan baik buruk dan benar salah suatu tindakan/perilaku sehingga mereka mampu mengaplikasikan nilai tersebut dalam kehidupan sehari-hari. Salah satu nilai dalam pendidikan moral yaitu Nasionalisme. Penanaman sikap nasionalisme penting sekali diajarkan sejak usia sekolah dasar. Karakter nasionalisme merupakan penilaian sikap dan tingkah laku peserta didik yang merujuk pada loyalitas dan pengabdian terhadap bangsa dan negaranya. ${ }^{23}$

Nasionalisme bangsa Indonesia melahirkan ideologi negara, yaitu Pancasila. Nasionalisme digunakan sebagai alat pemersatu adalah nasionalisme berlandaskan nilai-nilai Pancasila, yaitu perilaku yang mentauladani nilai ketuhanan, kemanusiaan, persatuan, permusyawaratan, dan keadilan. ${ }^{24}$ Karakter nasionalisme berdasarkan nilai-nilai Pancasila akan mewujudkan nasionalisme yang baik, yaitu mencintai bangsa sendiri tetapi masih menghargai bangsa lain. Sikap nasionalisme mencakup cinta tanah air, menghargai jasa para pahlawan, rela berkorban demi negara, mengutamakan kepentingan umum, membina persatuan dan kesatuan, bangga pada budaya yang beragam (multikultural), bangga sebagai warga negara Indonesia, sikap toleransi terhadap keragaman, cinta terhadap lingkungan, dan berkerja sama. ${ }^{25}$

Berdasarkan ulasan tersebut, karakter nasionalisme harus ditanamkan kepada anak sebagai generasi muda sejak usia dini sehingga nilai-nilai tersebut lebih mudah terinternalisasi dan menjadi kebiasaan positif dalam kehidupan sehari-hari anak. Nasionalisme yang sebaiknya ditanamkan kepada generasi muda yaitu

${ }^{23}$ Aman, Model Evaluasi Pembelajaran Sejarah(Yogyakarta: Ombak, 2011).

${ }^{24}$ Miftahuddin. "Nasionalisme Indonesia: Nasionalisme Pancasila.”Mozaik: JurnalIlmu-ilmu Sosial dan Humaniora, 4, 120.(2008): 1.

${ }^{25}$ An-Nisa Apriani dan Yusinta Dwi Ariyani. "Analisis Muatan Nilai-Nilai Nasionalisme Pada Buku Teks KTSP PKn Kelas 3 SD."ELEMENTARY SCHOOL (Jurnal Pendidikan dan Pembelajaran Ke-SD-an), no 2 (2017): 65. 
nasionalisme nusantara yang berlandaskan nilai-nilai Pancasila sehingga terwujudnya sikap dan perilaku yang positif.

\section{Generasi Alpha}

Menurut McCrindle, generasi alpha adalah istilah khusus untuk kategori orang-orang yang lahir pada tahun 2010 dan setelahnya. Mereka akan bermain, belajar, dan berinteraksi dengan teknik baru. ${ }^{26}$ Mereka dilahirkan di era digital, perangkat teknologi berada pada tingkat kecerdasan yang tinggi, lingkungan fisik dan digital saling terhubung dan berkaitan menjadi satu. Ketika mereka tumbuh dewasa, teknologi menjadi bagian hidup mereka dan akan membentuk pengetahuan, pengalaman, sikap, perilaku dan impian mereka terhadap dunia.

Gen Alpha merupakan anak-anak yang lahir dari generasi millenial, mereka sangat akrab dengan internet sepanjang masa, tumbuh berinteraksi dengan ragam teknologi (kecerdasan buatan) dan robot layaknya manusia. ${ }^{27}$ Generasi Alpha adalah generasi muda yang tidak bisa lepas dari gadget, kurang bersosialisasi, kurang daya kreativitas, dan bersikap individualis. Generasi Alpha menginginkan hal-hal yang instan dan kurang menghargai proses. Keasyikan mereka dengan gadget membuat mereka jauh dari kehidupan secara sosial.

Istiqomatunnisa, N., Kuswandi, D., \& Toenlioe, A. J. menambahkan bahwa generasi tersebut lebih dikenal dengan Digital Native Nitizen lahir dan berkembang di era Internet. Anak-anak yang tumbuh pada generasi Alpha dalam kesehariannya tidak lepas dari penggunaan gadget, sehingga mempengaruhi mereka dalam aktifitas sehari-hari seperti

${ }^{26}$ Erfan Gazali. "Pesantren Di Antara Generasi Alpha Dan Tantangan Dunia Pendidikan Era Revolusi Industri 4.0." Oasis: Jurnal Ilmiah Kajian Islam, no 2 (2018): 96.

${ }^{27}$ An Ras Tri Astuti, dkk. "Tantangan Parenting dalam Mewujudkan Moderasi Islam Anak.” Jurnal AlMaiyyah, no 2. (2018): 309. gayabelajar hingga hubungan sosial. ${ }^{28}$ Dengan demikian,lingkungan keluarga, sekolah, dan masyarakat memiliki peranan penting dalam mendidik anak yang berkarakter baik.

Anak-anak yang dibesarkan di era kemajuan teknologi mengakibatkan mereka memiliki sikap lebih pragmatis, materialistis, berpikir praktis, kurang memperhatikan nilai, dan lebih egois di banding generasigenerasi sebelumnya. Oleh karena itu, mereka perlu mendapatkan bekal penguatan karakter nasionalisme untuk menghadapi era digital yang menyajikan informasi dan budaya yang tidak sesuai dengan nilai-nilai Indonesia. Trilogi pendidikan yakni lingkungan keluarga, sekolah, dan masyarakat wajib memberikan penguatan pendidikan karakter untuk membentengi generasi alpha terhadap dampak negatif dari perkembangan teknologi.

Mendidik generasi alpha perlu memperhatikan beberapa hal yaitu mengikuti perkembangan teknologi informasi, mengasah kemampuan sosial, ajak anak untuk aktif bergerak, membekali nilai moral, dan mencegah kecanduan teknologi. Salah satu yang dasar dalam menjalani kehidupan yang serba canggih adalah penanaman dan penguatan nilai nasionalisme. Bekali anak-anak dengan nilainilai nasionalisme sehingga mereka tertanam nilai-nilai positif dan mampu memilah mana yang baik dan mana yang buruk berdasarkan konten-konten digital yang mereka dapatkan.

\section{Living Values Education Program (LVEP)}

LVEP adalah program pendidikan yang menyediakan kesempatan bagi anak-anak dan remaja untuk menggali serta mengembangkan dua belas nilai-nilai universal: kerjasama, kebebasan, kebahagiaan, kejujuran, kerendahan hati, cinta, kedamaian, penghargaan, tanggung jawab, ksederhanaan, toleransi,dan

\footnotetext{
${ }^{28}$ Nurul Istiqomatunnisa, Dedi Kuswandi, dan Anselmus JE Toenlioe. "Aplikasi Android Al-Amtsal (Kisah Teladan) Sebagai Media Pembelajaran Mengenal Kisah Al-Quran Dengan Cerita Animasi Bagi Anak Generasi Alpha.”Jurnal Kajian Teknologi Pendidikan, no 1 (2018)
} 
persatuan. ${ }^{29}$ Kegiatan pembelajaran yang dikemas dalam program pendidikan Living Values, mencakup aktivitas-aktivitas nilai. Aktivitas tersebut tidak hanya mengajak anak mempelajari nilai tetapi mengalami dan menjadikan nilai-nilai tersebut bagian dalam hidup mereka. Dengan demikian, mereka tidak hanya membawa nilai-nilai ke dalam kehidupan pribadi melainkan ke dalam masyarakat luas.

Aktivitas nilai dalam LVEP meliputi aktivitas komunikasi, refleksi, imajinasi, relaksasi, ekspresi seni, pengembangan diri, ketermapilan sosial, dan kesadaran kognitif tentang keadilan sosial. Aktivitas pendidikan Living Values yang lain berupa kegiatan artistik, lagu, tarian permainan dan diskusi dengan tujuan memancing pikiran, menyenangkan, membantu siswa mengeksplorasi dampak dari berbagai sikap dan perilaku ${ }^{30} L V E P$ memiliki tiga asumsi dasar yaitu (a) Nilai-nilai universal mengajarkan prinsip penghargaan dan kehormatan untuk semua manusia. (b) Setiap Peserta didik memperhatikan nilai-nilai dan belajar dengan positif. (c) Peserta didik belajar berdasarkan nilai dalam lingkungan positif dengan sikap saling menghargai dan kasih sayang. ${ }^{31}$

Berdasarkan uraian di atas, nilainilai universal dalam program pendidikan Living Valuesmengajarkan penghargaan dan kehormatan untuk setiap orang dan semua orang. Sehingga mereka tidak sekedar mempelajari nilai-nilai tersebut namun mengalami dan menghayati nilai-nilai kehidupan dalam keseluruhan hidupnya sehingga dapat meningkatkan keberadaan bagi individu sebagai anggota masyarakat.

\section{Penguatan Karakter dengan Living Values Education Program (LVEP)}

Karakter siswa SD bersifat dinamis, kadang baik kadang buruk. Hal tersebut dikarenakan siswa SD memiliki karakter

${ }^{29}$ Diane Tillman, Living Values Activities For Children Ages 8-14 (Jakarta: Gamedia, 2004).

${ }^{30}$ Ibid., hlm. xiv-xv.

${ }^{31}$ Ibid., hlm. xiii-xiv. yang masih labil sehingga perlu ada program penguatan karakter dari lingkungan sekolah sebagai lembaga pendidikan yang dipercaya orang tua dan masyarakat. Tanggung jawab penguatan karakter bagi siswa di lingkungan SD dibebani pada guru kelas. Guru kelas memiliki peran yang besar dalam penguatan karakter siswa SD. Guru kelas memiliki waktu yang lebih banyak dengan siswa dari awal hingga akhir pembelajaran.

Guru kelas harus inovatif dan kreatif dalam pemilihan dan penggunaan suatu strategi penguatan karakter yang bermakna baik dari aspek moral knowing, moral feeling, dan moral acting. Banyak pilihan strategi pembelajaran yang bisa digunakan guru kelas, tapi salah satu strategi pembelajaranyang mampu memperkuat karakter anak dalam pembelajaran tematik sesuai dengan kurikulum yang digunakan baik KTSP maupun kurikulum 2013 adalah LVEP. Strategi tersebut dirancang untuk mengajak anak-anak berefleksi, berimajinasi, berdialog, berkomunikasi, berkreasi, membuat tulisan, dan bermain dengan nilai-nilai kehidupan. ${ }^{32}$ Dengan kata lain, proses penguatan karakter melalui LVEP maka keterampilan anak akan berkembang seperti keterampilan komunikasi, berpikir kritis, pribadi, sosial, dan emosional. LVEP memiliki sejumlah tujuan yaitu (a) Membantu individu memikirkan dan merefleksikan nilai-nilai yang beragam sehingga mampu mengekspresikan nilai-nilai tersebut. (b) Memperdalam pemahaman, motivasi, dan tanggung jawab dalam menentukan pilihan pribadi dan sosial. (c) Menginspirasi individu dalam memilih nilai-nilai pribadi, sosial, dan spiritual serta menyadari metode-metode dalam memperdalam nilai. (d) Mendorong para pendidik untuk memfasilitasi pertumbuhan dan perkembangan. ${ }^{33}$

LVEP sebagai upaya perbaikan kualitas pendidikan nilai dalam pendidikan Indonesia, panduan mendidik anak-anak, dan upaya dalam pembentukan generasi muda yang

\footnotetext{
${ }^{32}$ Ibid., hlm. xiii.

${ }^{33}$ Ibid., hlm.x.
} 
berkarakter, berbudi pekerti luhur, cerdas, kreatif dan berakhlaq mulia. Aplikasi LVEP sebagai penguatan pendidikan karakter dapat dilaksanakan melalui integrasi dalam bidang studi maupun pembelajaran tematik. Integrasi dalam kegiatan pembelajaran tematik dilakukan melalui integrasi nilai-nilai hidup dalam materi, metode, media, sumber belajar dan penilaian. Selain itu, integrasi dalam kegiatan pembelajaran dan ekstrakurikuler mampu membangun berbagai nilai-nilai hidup. Integrasi LVEP dalam pembelajaran memberikan efek yang signifikan pada perilaku dan sikap tertentu yang terkait dengan kecerdasan pribadi (intrapersonal dan interpersonal) pada siswa SD. ${ }^{34} L V E P$ juga dapat dilakukan melalui pembelajaran sastra anak. LVEP dalam pembelajaran sastra anak mampu meningkatkan hasil belajar dan implementasi nilai-nilai budi pekerti anak (menaati ajaran agama, tanggung jawab, cinta dan kasih sayang, dan kerja sama. ${ }^{35}$

Berdasarkan ulasan tersebut,LVEP dapat membantu menanamkan dan memperkuat karakter pada anakdengan integrasi nilai-nilai hidup dalam bidang studi maupun pembelajaran tematik. Strategi LVEP tidak hanya membantu anak mengetahui dan memahami nilai tetapi mampu merasakan dan mengaplikasikan nilai-nilai tersebut dalam kehidupan pribadi dan masyarakat luas. LVEP juga berupaya memperbaiki kualitas pendidikan nilai di Indonesia sehingga terwujudnya generasi muda yang cerdas, trampil, dan berkarakter baik.

\footnotetext{
${ }^{34}$ Dhiah Intan Permataputri. "Penerapan Living Values Education Program (LVEP) Di Ra Tiara Chandra, Kecamatan Sewon, Kabupaten Bantul, Yogyakarta."Jurnal Pendidikan Anak Usia Dini Edisi 10 Tahun ke-5 (2016).Di unduh pada tanggal 29 Agustus 2019. Darihttp://www.e-jurnal.com/2017/05/penerapanliving-values-education.html

${ }^{35}$ Muhammad Arafik. 2010. Living Values Education Program dalam pembelajaran sastraanak untuk meningkatkan nilai-nilaibudi pekerti siswa SD. Tesis, tidakditerbitkan. Yogyakarta: ProgramPascasarjana Universitas NegeriYogyakarta.
}

\section{Penguatan Karakter Nasionalisme Generasi Alpha dengan Living Values Education Programdi Era Digital}

Generasi Alpha merupakan generasi yang lahir di era digital yang dikelilingi kemajuan teknologi. Apabila pendidikan anak-anak tidak diimbangi dengan penanaman karakter sejak usia dinimaka berakibat sangat fatal, karena dapat mengakibatkan pertumbuhan individualis pada anak serta pertumbuhan motoris dan emosional yang tidak maksimal. ${ }^{36}$ Tantangan terbesar bagi generasi alpha seiring dengan kemajuan teknologi adalah pembekalan pendidikan karakter sejak usia dini. PPK merupakan salah satu perantara untuk melakukan pembenahan secara menyeluruh terhadap Pendidikan karakter. PPK bertujuan memperkuat Kurikukum 2013 yang sudah memuat pendidikan karakter itu. Dalam penerapannya, dilakukan sedikit inovasi agar praktik pembelajaran tematik memiliki muatan pendidikan karakter.Salah satu nilai karakter utama yang menjadi prioritas pengembangan gerakan PPK yaitu nasionalisme.

Penguatan karakter nasionalisme bagi anak perlu dilakukan sejak usia dini. Apriani, A. N., \& Ariyani, Y. D. menambahkan bahwa penanaman sikap nasionalisme penting sekali diajarkan sejak usia dini agar lebih melekat saat mereka dewasa. ${ }^{37}$ Karakter nasionalisme perlu ditanamkan sedini mungkin untuk mendukung pembangunan sumber daya manusia Indonesia yang berkualitas. Penanaman karakter nasionalisme dapat dilakukan di lingkungan keluarga, sekolah, dan masyarakat secara konsisten. Penanaman karakter nasionalisme melalui sekolah sangatlah penting karena sekolah menjadi penghubung antara orang tua

${ }^{36}$ Marissa Indrayana, Hendro Aryanto, dan Aniendya Christianna. "Perancangan Buku Interaktif Pembelajaran Pengembangan Karakter Pada Generasi Alpha."Jurnal DKV Adiwarna, no 12 (2018):

${ }^{37}$ An-Nisa Apriani dan Yusinta Dwi Ariyani. "Analisis Muatan Nilai-Nilai Nasionalisme Pada Buku Teks KTSP PKn Kelas 3 SD."Elementary School (Jurnal Pendidikan dan Pembelajaran Ke-SD-an), no 2 (2017): 174. 
dan masyarakat dalam menguatkan pendidikan. Penanaman karakter nasionalisme tersebut dapat dilakukan dalam kegiatan pembelajaran maupun diluar kegiatan pembelajaran.

Pembelajaran yang kental dengan karakter nasionalisme dibutuhkan strategi pembelajaran yang menanamkan nilai-nilai moral yang universal untuk semua orang tidak melihat suku, agama, dan budaya. Salah satu strategi pembelajaran yang dapat digunakan adalah LVEP. Strategi tersebut dapat diintegrasikan dalam pembelajaran tematik. LVEP yang diintegrasikan dalam pembelajaran tematik berpengaruh positif dalam menanamkan subkarakter nasionalisme dalam pembelajaran tematik: tanggung jawab, toleransi, kerja sama, persatuan, cinta, penghargaan, dan kedamaian. ${ }^{38}$

Penggunaan $L V E P$ dalam pembelajaran mampu memberikan pengalaman langsung sebagai dasar untuk memahami sub karakter nasionalisme yang abstrak sehingga mereka mudah memahami tentang pentingnya karakter nasionalisme secara langsung dalam kehidupan sehari-hari. Penggunaan LVEP dalam pembelajaran tematik juga mampu membantu siswa memahami konsep materi dan sub karakter nasionalisme secara holistik. Pembelajaran tematik dengan LVEP juga menjadikan pembelajaran lebih kreatif, variatif, inovatif, dan menyenangkan dengan berbagai kegiatan dan siswa memahami sub karakter nasionalisme secara mendalam dalam jangka waktu lama. ${ }^{39}$

Aktivitas-aktivitas yang ada di LVEP dirancang untuk memotivasi siswa dan mengajak mereka untuk memikirkan diri sendiri, orang lain, dan dunia. Para siswa diajak untuk berefleksi, berimajinasi, berdialog, berkomunikasi, berkreasi, membuat tulisan,

\footnotetext{
${ }^{38}$ Diane Tillman, Living Values Activities For Children Ages 8-14 (Jakarta: Gamedia, 2004).

${ }^{39}$ An-Nisa Apriani, Indah Perdana Sari, dan Intan Kurniasari Suwandi. "Pengaruh Living Values Education Program (LVEP) Terhadap Penanaman Karakter Nasionalisme Siswa SD Dalam Pembelajaran Tematik." Taman Cendekia: Jurnal Pendidikan Ke-SD-an, no 2 (2017): 102.
}

menyatakan diri lewat seni, dan bermain dengan nilai-nilai yang diajarkan. Dalam prosesnya akan berkembang keterampilan pribadi, sosial, dan emosional. Berikut uraian tentang aktivitasaktivitas LVEP yang membantu guru dalam proses menguatkan karakter nasionalisme generasi alpha dalam pembelajaran. ${ }^{40}$

\section{Butir-butir Refleksi}

Butir-butir refleksi diletakkan di awal unit nilai dan dibaurkan dalam pembelajaran tematik. Butir-butir tersebut mendefinisikan nilai-nilai dan memberikan konsep abstrak untuk direnungkan. Misal, butir refleksi dalam unit toleransi adalah: tolerani berarti menerima keindahan perbedaan. Guru bisa menambahkan paribahasa sesuai budaya daerah setempat. Para siswa juga bisa membuat butir-butir refleksi sendiri sesuai kemampuan mereka.

\section{Berimajinasi}

Berimajinasi berarti membayangkan sebuah nilai untuk berbagi pengalaman mereka dan membuat gambar sesuai unit nilai. Berimajinasi bermanfaat memancing kreativitas semua siswa. Imajinasi membantu mereka mengalami sendiri nilai tersebit dan menghasilkan ide yang mereka miliki.

\section{Refleksi}

Refleksi berarti merenungkan sebuah nilai dalam kondisi hening. Latihan ini dirancang membnatu siswa menikmati "perasaan" dari nilai-nilai terseut. Latihan tersebut juga terbukti membantu siswa lebih puas diri dan lebih berkonsentrasi saat belajar.

\section{Ekspresi Seni}

Ekspresi seni mendorong anak berefleksi tentang nilai dan mengalami nilai tersebut melalui kesenian. Misal, mereka membuat poster kedamaian, gambar pelangi yang mencerminkan bahwa toleransi itu indah dan damai, membuat pohon sikap, membuat katakata damai dan menempelkan karya senin di

40 Ibid.,hlm. xiv-xvii. 
dinding atau menarikan kerja sama, dan melukis cinta dan kebahagiaan.

\section{Pengembangan Diri}

Aktivitas pengembangan diri mengajak siswa untuk mengeksplorasi nilai dalam kaitannya dengan diri mereka sendiri dan membangun keterampilan yang berkaitan dengan nilai. Misal, siswa melihat sifat baik diri sendiri dan orang lain. Ajak anak merenungkan perasaan mereka ketika mereka berlaku jujur. Guru bisa membacakan sebuah kisah yang berkaitan dengan nilai dan ajak siswa untuk diskusi terkait dengan nilai tersebut.

\section{Keterampilan Sosial}

Guru mengajarkan dan mencontohkan keterampilan penyelesain konflik. Dalam unit kedamaian, siswa ditugaskan menjadi pengawas kedamaian di tempat bermain saat istirahat. Dalam unit cinta, siswa mengeksplorasi caracara menggunakan kata-kata untuk orang lain. Dalam unit penghargaan, siswa-siswa memeriksa cara halus dan kurang halus yang menunjukkan menghargai dan menghina.

\section{Kesadaran kognitif tentang Keadilan Sosial}

Para siswa didorong untuk melihat akibat tindakan mereka pada orang lain dan bagaimana mereka bisa membuat perbedaan. Misal, dalam unit nilai kejujuran: siswa membuat drama singkat tentang kejujuran kemudia mereka bisa melihat pengaruh ketidakjujuran pada hidup orang lain dan guru bisa mengajukan pertanyaan pada siswa tentang perasaan mereka.

\section{Mengembangkan keterampilan untuk kerukunan sosial}

Unit toleransi, kesederhanaan, dan persatuan merupakan elemen tanggung jawab sosial yang menarik dan menyenangkan. Menggunakan warna pelangi sebagai analogi, anak bisa mengeksplorasi berbagai macam suku dan budaya di Indonesia. Dalam unit kesederhanaan, siswa diajak untuk melestarikan dan menghargai bumi kita. Para siswa bisa mengeksplorasi hal-hal positif dari persatuan dan bekerj sama dalam tugas bersama.

Berdasarkan ulasan tersebut, Living Values EducationProgram dapat diterapkan sebagai program unggulan dalam penguatan pendidikan karakter bagi anak-anak generasi alpha dalam proses pembelajaran baik terintegrasi dalam bidang studi maupun tematik. LVEP mencakup aktivitas-aktivitas nilai yang dirancang untuk mengajak generasi alpha untuk memikirkan diri sendiri, orang lain dan dunia. Aktivitasaktivitas tersebut mengajak anak-anak generasi digital untuk mendalami, mengalami, dan mengeksplorasitentang sikap nasionalisme dalam kehidupan sehari-hari sehingga peserta didik memperoleh pengalaman langsung yang bermakna. Pengalaman tersebut yang membuat anak-anak generas alpha memperoleh beragam keterampilan sosia yang berguna dalam menghadapi era digital.

\section{KESIMPULAN}

Berdasarkan kajian pustaka di atas bahwa generasi Alpha dalam kesehariannya tidak lepas dari penggunaan gadget, sehingga mempengaruhi mereka dalam aktifitas seharihari seperti gaya belajar, hubungan social, dan karakter. Untuk itu lingkungan keluarga, sekolah, dan masyarakat memiliki peranan penting dalam mendidik generasi alpha. Prioritas utama dalam pendidikan bagi generasi alpha adalah penguatan karakter. Salah satu nilai karakter yang penting di tanamkan bagi generasi alpha di era digital adalah penguatan nilai nasionalisme.

Salah satu strategi pembelajaran yang dapat digunakan adalah Living Values Education Program (LVEP). LVEP menawarkan berbagai pengalaman aktivitas nilai agar generasi alpha mampu menggali dan mengembangkan nilainilai kehidupan di era teknologi canggih, yakni: kedamaian, penghargaan, cinta, toleransi, kebahagiaan, tanggung jawab, kerjasama, kerendahan hati, kejujuran, kesederhanaan, kebebasan, dan persatuan. Melalui LVEP, mereka tertanam nilai-nilai positif dan mampu memilah baik buruknya sesuatu berdasarkan 
konten-konten digital yang mereka dapatkan. Secara keseluruhan, bahwa LVEP yang mencakup aktivitas refleksi, berimajinasi, berdialog, berkomunikasi, berkreasi, membuat tulisan, menyatakan diri lewat seni, dan bermain dengan nilai-nilai yang diajarkan dapat dijadikan metode inovatif dalam penguatan karakter nasionalisme generasi alpha di era digital.

LVEP memiliki manfaat yang tak terbatas khususnya dalam penguatan pendidikan karakter naisonalisme khusus generasi alpha yang hidup di era digital. Oleh karena itu, guru perlu menerapkan metode LVEP dalam pembelajaran baik tematik maupun bidang studi untuk menguatkan karakter nasionalisme generasi alpha. Selanjutnya, LVEP dapat dijadikan salah satu kebijakan yang bisa digunakan oleh kepala sekolah maupun pejabat pendidikan setempat guna membangun generasi emas Indonesia yang berkarakter nasionalisme di era digital.

\section{DAFTAR PUSTAKA}

Aman, Model Evaluasi Pembelajaran Sejarah. Yogyakarta: Ombak, 2011.

Anonim. "Nasionalisme di Era Digital." Diunduh pada tanggal 28 Agustus 2019. Dari http://www.tribunnews.com/ nasional/2016/03/29/nasionalisme-eradigital.

An Ras Tri Astuti, dkk. "Tantangan Parenting dalam Mewujudkan Moderasi Islam Anak." Jurnal Al-Maiyyah, no 2 (2018).

Apriani, An-NisadanYusinta Dwi Ariyani. "Analisis Muatan Nilai-Nilai Nasionalisme Pada Buku Teks KTSP PKn Kelas 3 SDELEMENTARY SCHOOL (Jurnal Pendidikan dan Pembelajaran $K e-S D$-an), no 2 (2017).

Apriani, An-Nisa, Indah Perdana Sari, dan Intan Kurniasari Suwandi. "Pengaruh Living Values Education Program (LVEP) Terhadap Penanaman Karakter Nasionalisme Siswa SD Dalam Pembelajaran Tematik." Taman Cendekia: Jurnal Pendidikan Ke-SD-an, no 2 (2017).
Arafik, Muhammad. 2010. Living Values Education Program dalam pembelajaran sastraanak untuk meningkatkan nilai-nilaibudi pekerti siswa SD. Tesis, tidakditerbitkan. Yogyakarta: ProgramPascasarjana Universitas NegeriYogyakarta.

Arifudin, Iman Syahid. "Peranan Guru Terhadap Pendidikan Karakter Siswa Di Kelas V Sdn 1 Siluman." Pedadidaktika: Jurnal Ilmiah Pendidikan Guru Sekolah Dasar, no 2 (2015).

Budhiman, Arie. "Gerakan Penguatan Pendidikan Karakter."Diunduh pada tanggal 24 Agustus 2019. Dari cerdasberkarakter. kemdikbud.go.id/ content/download/44.

Dhiah Intan Permataputri. "Penerapan Living Values Education Program (LVEP) Di Ra Tiara Chandra, Kecamatan Sewon, Kabupaten Bantul, Yogyakarta." Jurnal Pendidikan Anak Usia Dini Edisi 10 Tahun ke-5 (2016). Di unduh pada tanggal 29 Agustus 2019. Darihttp://www.ejurnal.com/2017/05/penerapan-livingvalues-education.html

Gazali, Erfan. "Pesantren Di Antara Generasi Alpha Dan Tantangan Dunia Pendidikan Era Revolusi Industri 4.0.”Oasis: Jurnal Ilmiah Kajian Islam, no 2 (2018).

Harahap, Nursapia. "Penelitian Kepustakaan." Jurnal Iqra', no 1 (2014).

Hasan, Yetri dan Firdaos, Rijjal. "Penguatan Pendidikan Karakter Berbasis Masyarakat Pada Sekolah Menengah Pertama Negeri (SMPN) Di Kabupaten Tulang Bawang Provinsi Lampung."Al-Tadzkiyyah: Jurnal Pendidikan Islam, no 2 (2018).

Hendrastomo, Grendi. "Nasionalisme vs Globalisasi 'Hilangnya' Semangat Kebangsaan dalam Peradaban Modern." DIMENSIA, no.1 (2005).

Indrayana, Marissa, Aryanto, Hendro,dan Christianna, Aniendya. "Perancangan Buku Interaktif Pembelajaran Pengembangan Karakter Pada Generasi Alpha”. Jurnal DKV Adiwarna, 1(12), 10. (2018). 
Istiqomatunnisa, Nurul, Kuswandi, Dedi, danAnselmus JE Toenlioe. "Aplikasi Android Al-Amtsal (Kisah Teladan) Sebagai Media Pembelajaran Mengenal Kisah Al-Quran Dengan Cerita Animasi Bagi Anak Generasi Alpha." Jurnal Kajian Teknologi Pendidikan, no 1 (2018).

Kemendikbud Republik Indonesia, 2016. Kajian dan Pedoman Penguatan Pendidikan Karakter (PPK). Jakarta: Kementerian Pendidikan dan Kebudayaan Republik Indonesia.

Kemendikbud Republik Indonesia, 2017. Kajian dan Pedoman Penguatan Pendidikan Karakter (PPK). Jakarta: Kementerian Pendidikan dan Kebudayaan Republik Indonesia.

Khatibah, Khatibah. "Penelitian kepustakaan." Iqra': Jurnal Perpustakaan dan Informasi, no 1 (2011).

Miftahuddin. "Nasionalisme Indonesia: Nasionalisme Pancasila." Mozaik: JurnalIlmu-ilmu Sosial dan Humaniora, 4, 120. (2008).

Nurhaidah Musa, M. Insya. "Dampak Pengaruh Globalisasi Bagi Kehidupan Bangsa Indonesia”. Jurnal Pesona Dasar, no.3 (2015).
Nasirudin. "Peran Keluarga, Sekolah, dan Masyarakat Dalam Pendidikan Karakter Generasi Muda Bangsa." Prosiding Seminar Nasional Tahunan Fakultas Ilmu Sosial Universitas Negeri Medan, no 1 (2017).

Purnomo, Sigit. "Pengasuhan Digital Untuk Anak Generasi Alpha." Al Hikmah Procedings on Islamic Early Childhood Educatiion, no 4 (2018).

Rachmadyanti, Putri. "Penguatan Pendidikan Karakter Bagi Siswa Sekolah Dasar melalui Kearifan Lokal." Jurnal Pendidikan Sekolah Dasar, no 2 (2017).

Rufaidah, Anne. "Menyongsong Tantangan Nasionalisme di Era Digital." Diunduh pada tanggal 20 Agustus 2019. Dari https:// kemahasiswaan.itb.ac.id/welcome/ tampil_berita/107/menyongsongtantangan-nasionalisme-di-era-digital.

Sukmadinata, N. S, Metode penelitian. Bandung: PT Remaja Rosda Karya, 2011.

Tillman, Diane. Living Values Activities For Children Ages 8-14. Jakarta: Gamedia, 2004.

Zubaedi, Desain Pendidikan Karakter: Konsespsi dan Aplikasinya dalam Lembaga Pendidikan. Jakarta: Prenada Media Grup, 2015. 